\title{
COST MANAGEMENT IN THE INTERNAL VALUE CHAIN OF INTEGRATED APPLICATION OF ACTIVITY-BASED COSTING, KAIZEN CONCEPT AND TARGET COSTING
}

\begin{abstract}
The objective of this paper is an effort to view the possibilities of integrated use of target costing, activity based costing and Kaizen concept in the internal value chain as the central link of the entire chain. The idea is to stimulate the company management to think about the costs, position they take in the structure of price cost and their influence on forming the sales price since it is very important to produce right product for the consumer, of desired quality and functionality but along with as low production costs as possible. It is therefore needed to construct the right design of a product and provide its production at the shortest possible time along with as low costs as possible which will impact the efficiency of the entire value chain.
\end{abstract}

Key words: integrated application, Activity Based Costing, Kaizen Costin, Target Costing, internal value chain

\section{Introduction}

In business environment characterized by uncertainty and turbulence, cost management becomes the crucial factor of a company's success and keeping and upgrading of its competitiveness. In an effort to create a successful business strategy that might respond to all challenges of modern environment, company management has to possess a quality database that could generate various information upon request.

Michael Porter, creator of the concept of generic strategies emphasizes that the competitive advantage is the essence of all strategies and the selection of a strategy is actually the selection of type and size of competitiveness that a company wants to achieve. ${ }^{1}$ Among generic strategies, costs leadership strategy deserves special attention; by selecting it a company aspires to achieve the

Vesna Pašić Tomić, Msc, Assistant, Faculty of management in Zajecar, Megatrend University,Belgrade e-mail: vesna.pasic@fmz.edu.rs

** Maja Andrijasevic, PhD, Aassistant professor, Faculty of management in Zajecar, Megatrend University,Belgrade, e-mail: maja.andrijasevic@fmz.edu.rs

1 M. Porter, 1996 „What is Strategy“, Harvard Business Review, November December, p. 68 
most favorable costs position in an industry which enables it to achieve price competition.

Competitive advantage, and therefore generating value for stakeholders, is possible to achieve by efficient application of well-formulated business strategy, adequate value chain analysis directed towards identification of activities creating value and establishing relations between them, which should contribute to the increased product competitiveness - either by reduction of costs or improvement of quality and functionality.

However, with the change in business conditions, where the change is the only constant, there appears a new strategy being more compatible to new business conditions and is called confrontation strategy. Radical changes in modern business environment forced companies to realize that generating value is no longer the question of one company but the entire value chain since today it is no longer enough to be the best in an industry but it is necessary to be part of the most successful value chain. ${ }^{2}$ In other words, an internal value chain of a company is part of the total value chain including supply chain and distribution chain. (Figure 1)

Figure 1: Integrated value chain of a company ${ }^{3}$
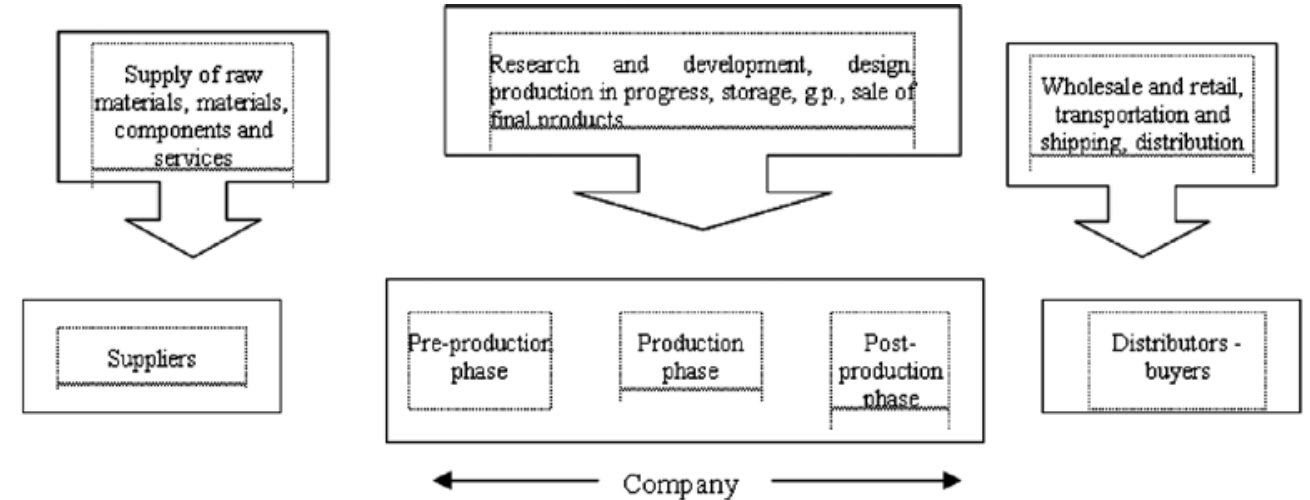

Supply chain

Internal value chain

Distribution chain

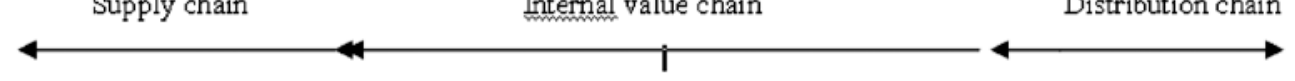

Therefore, companies, in today's business conditions, must strategically manage costs in the entire value chain which creates the need for integrated

$2 \quad$ V. Sekerez "Virtual Supply Chains as a Framework for Integrated Costs Management in Supply Chain" Available on the Internet

3 S.Malinic, D. Jovanovic, 2011., Implementation of Integrated Concepts of Cost Management in Value Chain - Strategic Approach TC and ABC, Accounting 11-12, Association of Auditors and Accountants of Serbia, Belgrade, p. 31 
application of two or more systems and concepts of costing throughout the entire value chain. Aspiration of a company to achieve competitive position at the segmented market through efficient production, cost management and successful implementation of costs leadership strategy within the value chain, and, above all within internal chain, is a stimulus for integrated application of modern concepts of cost management.

The objective of this paper is an effort to view the possibilities of integrated use of target costing, activity based costing and Kaizen concept in the internal value chain as the central link of the entire chain. The idea is to stimulate the company management to think about the costs, position they take in the structure of price cost and their influence on forming the sales price since it is very important to produce right product for the consumer, of desired quality and functionality but along with as low production costs as possible. It is therefore needed to construct the right design of a product and provide its production at the shortest possible time along with as low costs as possible which will impact the efficiency of the entire value chain.

The need to consider costs incurred in the process of design and development of the product, as well as the costs in post-production phases requires finding new concepts of calculation and management of costs such as, among others, activity-based costing, target costing and Kaizen costing. Application of modern systems of costing and their integration in the process of cost management would provide a quality database that would be the basis for making business decisions.

Researches in the area of management accounting confirmed that the greatest savings in costs can be achieved in pre-production phase, i.e. in product design phase and target costing as market-oriented system of costing is characteristic for pre-production phase and is directed towards achieving of the target costing of product production.

Activity based costing is characteristic for production phase and part of preproduction phase related to the phase of achieving of target cost. Significance of application of $\mathrm{ABC}$ lies in providing precise information on the product price cost and on global costs that take over $60 \%$ in the structure of product costs.

Kaizen costing is a modern concept of cost management located in the production phase and is the upgrading of Target costing. The essence of Kaizen costing is small but constant incremental improvements contributing to the desired cost reduction.

We think that the integrated application of the mentioned systems of cost accounting in the internal value chain can have a synergy effect on operating costs. 


\section{The need for strategic cost management}

Classic method of costs management having taken into account only one phase of product life cycle was questioned in what way one observed the tendency of increasing the costs generated before the production process began, while, in the other hand, the phase of product maturity showed the tendency of shortening. All these brought about the need to expand the scope of cost management over the entire product life cycle. ${ }^{4}$ Product life cycle becomes shorter so the focus of costs management moves from production phase to the phases of research, planning and design of product. Therefore there appeared the need to revise the traditional systems of costing that pointed to the need to create new modern systems of calculation characterized by significantly wider horizon of the scope and vision of achievement. ${ }^{5}$

Modern business conditions have shown that the information collected by using traditional cost accounting systems is not adequate for business decision making. The first to show the weaknesses of traditional cost accounting systems in their works were Robin Cooper and Robert Kaplan.The main objection to traditional cost accounting systems is the allocation of overhead costs based on direct labour costs. ${ }^{6}$ At a time when traditional cost accounting systems were developed, companies operated in stable conditions with a narrow range of products so that cost accounting gave accurate information since the participation of overhead costs in total costs was small and the error probability was negligible. However, over time, business conditions have intensified, competition has grown stronger, buyers and their satisfaction have become the focus of company interest, and so strategic cost management has become an imperative for the company. Under such operating conditions, the use of traditional cost accounting systems provided information which helped managers bring wrong decisions that cost the company's survival.

The emergence and implementation of new cost accounting systems have enabled the company to manage costs more easily because they are able to perceive the behavior of the costs from the strategic perspective which allows them to take steps to reduce these costs if they want not to gain a competitive position, but to preserve their survival on the market. Strategic cost management

$4 \quad$ Novicevic B., Antic LJ., 2000, "New Concept of Cost Management - Target Costing Calculation", Accounting 9, Association of Accountants of Serbia, Belgrade, ps. 13-20

5 Lalevic-Filipovic A., 2012, Possibility of Information Support to Target Costing by Generic Strategies of the Company", Accounting 1-2, Association of Accountants of Serbia, Belgrade, ps. 21-30

6 Cooper Robin , Caplan S. Robert., (1988),"How Cost Accounting Distors Products Cost“, Management Accounting, April, pp.20-27., Cited according Vlade Milićević (2008) Conventional management accounting - strategic issues", Economics of Enterprise, vol.56, br.3-4, Serbian Association of Economists,ps. 144-154 
brings a completely new strategic dimension in the process of planning and cost control, which contributes to cost reduction and better company performance.

As Porter noticed a long time ago, a company seeks the basis ofcompetition in providing a greater value to customers at the same costs or in delivering an equivalent value at lower costs. Regardless of the chosen strategy, reducing costs at an optimal level for every individual activity or process is the foundation for delivering superior value of the final goods and services on the market. The application of the strategic cost analysis in this context is intended to help detect the processes and activities whose value can be increased and costs decreased.

Regardless of the chosen strategy,cost management must be done intelligently and carefully as the choice of any strategy does not eliminate the problem of cost effectiveness. Having all these in mind, the managers of a company need the support of strategic accounting management that is facing the future and highlighting the company's competitive position. It establishes a connection with other departments in the company and uses their knowledge to obtain relevant information for making strategic decisions.

Together with the managers, it goes beyond the company, trying to act proactively and anticipate the competition's cost structure, measuring in relative terms the amounts and changes in their costs and revealing the ways to cut costs through a partnership link with suppliers, distributers and buyers. From this perspective, cost management has a completely new dimension - strategic cost analysis.?

The objective of strategic cost analysis is to highlight the position of the company in relation to its competition and to use the information obtained through the analysis for gaining a sustainable competitive advantage. In order for the obtained cost information to be relevant for making strategic decisions, the strategic cost analysis must be conducted continuously over a long period of time, because it tracks costs in individual phases along the whole length of the value chain in which a company represents only one part of the entire value chain.

More on strategic cost analysis look at the book Milićević Vlade (2003), Strategic Management Accounting, Faculty of Economics, Belgrade, p. 130 
Table.1: Main characteristics of strategic management accounting and strategic cost analysis ${ }^{8}$

\begin{tabular}{|l|l|l|}
\hline \multicolumn{1}{|c|}{$\begin{array}{c}\text { Characteristics of strategic } \\
\text { management accounting }\end{array}$} & \multicolumn{2}{c|}{ Characteristicof strategic cost analysis } \\
\hline Focused on the future & Focus & External \\
\hline Follow the relations between companies & The main objective & Create a competitive advantage \\
\hline Deflection of the period & Timeline & Long term \\
\hline Directed to the more activity & The kay concept & $\begin{array}{l}\text { The concept of the industrial value } \\
\text { chain }\end{array}$ \\
\hline Openly & frequency & Ongoing \\
\hline Focused on competition & Cost drivers & $\begin{array}{l}\text { Multiple and single drivers of cost } \\
\text { for every value activity }\end{array}$ \\
\hline $\begin{array}{l}\text { Includes possible activities } \\
\text { Proactive }\end{array}$ & The philosophy of \\
Unprogrammed & $\begin{array}{l}\text { The function estimates the } \\
\text { relative cost position of enterprises } \\
\text { diagnose drivers of the cost value } \\
\text { of each activity, and discusses the } \\
\text { effects of internal and external } \\
\text { links connecting companies with } \\
\text { customers and suppliers }\end{array}$ \\
\hline $\begin{array}{l}\text { Establish relationships with others } \\
\text { Do not depend on the existing system } \\
\text { Ignore conventions }\end{array}$ & Illuminating strategic \\
decisions & $\begin{array}{l}\text { Directly to the adoption of } \\
\text { superior strategies through the } \\
\text { development of a sustainable } \\
\text { competitive advantage through } \\
\text { better control of costs drivers and } \\
\text { reconfiguration of the value chain. }\end{array}$ \\
\hline
\end{tabular}

\section{Integrateed application of modern costing systems}

In steady conditionsof business operations, information was not given great importance because the costs of its gathering and processing were higher than its total contribution to business operation.

In a business environment characterized by uncertainty and volatility, cost management becomes a critical factor of a company's success, preservation and competitiveness. In an effort to create a successful business strategy that will be able to respond to all the challenges of the modern environment, the management of the company must have a quality database which will be able to generate a variety of information at their request. It is with the changing business conditions that the power of information grows rapidly and, today, it

$8 \quad$ Milićević Vlade (2004),. ps.120-132 
is the foundation on which the companies build their competitiveness. That is why modern companies point out the need to build and implement modern cost accounting management techniques because they are aware that their competitive strength lies in their information offer.

Radical changes in modern business environment have forced companies to realize that generating value is no longer a question of one company but of the entire value chain, because today it is no longer enough to be the best in the industry but it is necessary to be part of the most successful value chain. ${ }^{9}$ In other words, the internal value chain of the company is part of the entire value chain which includes the supply chain and distribution chain..

The internal value chain consists of the company with its internal processes and logistics. The internal logistics of the company consists of all the internal activities starting from the procurement of materials and parts from the supplier, through production, up to product and service delivery to the customers. The objective of internal logistics management is amore efficient and more effective performance of the mentioned activities so as to deliver the products to the customers in time without compromising the required performances. ${ }^{10}$

Internal value chain is the central link of the total value chain whose functioning is impossible without it. Classical costing systems included only production phase of internal value chain which, with the change of business conditions created the problem for managers when making business decisions since classical costing systems did not provide the adequate accountinginformation support to the decision-making system. In other words, managers and management accountants timely observed that the basic characteristic of classical costing systems was that accounting monitoring and informing "start too late and end too early". New solutions in terms of achieving and keeping of the costs competitiveness were sought for in conceptualizing new organizationalaccounting solutions compatible with the information requirements of the modern concepts of costs management that extend their focus from production to both pre-production and post-production phase, which, graphically can be illustrated in the following manner:

Sekerez Vojislav (2011).

10 More on internal logistics companies read the paper Sekerez Vojislav (2007) „The concept of cost management through the supply chain "', Proceedings of Symposium 38 Accounting and Business Finance in contemporary business conditions; Association of Auditors and Accountants of Serbia ps. 65-80.

11 S. Malinic, 2008, "Management Accounting“, Faculty of Economics, Kragujevac, p. 239. 
Figure 2: Modern concepts of costing systems classified by stages of the production cycle at the company level ${ }^{12}$

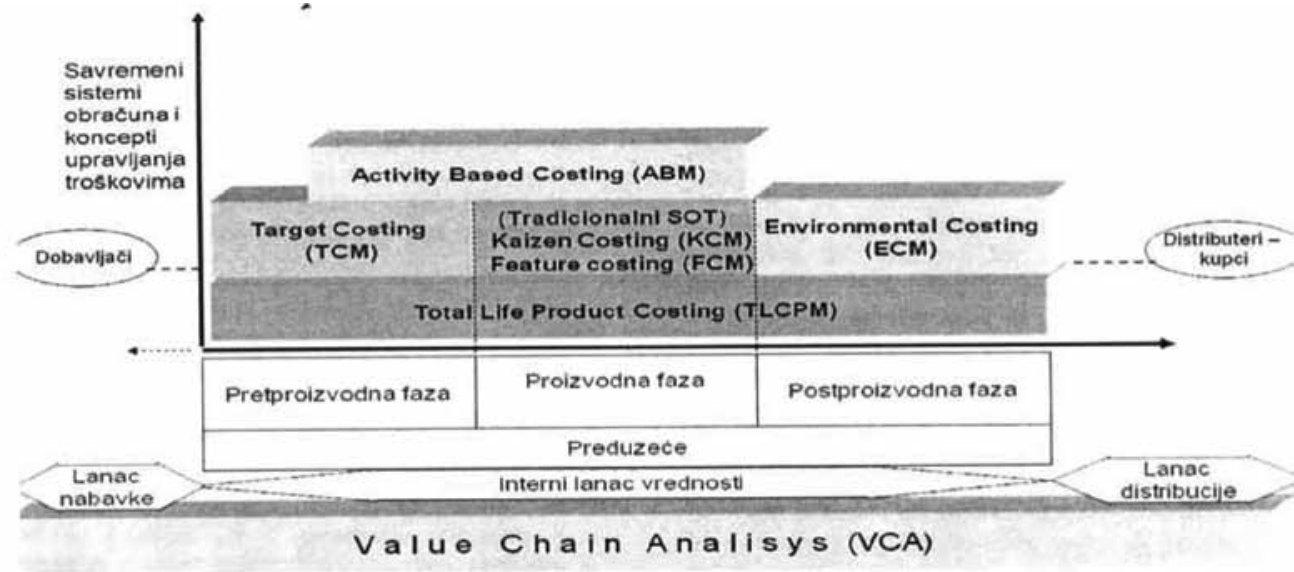

However, application of a single costing concept and cost management does not enable identification of the main costs drivers in the internal value chain or the effective measurement and control of costs out the limits of internal value chain. Achieving of synergy effects, not only of internal but the entire value chain, requires integrated use of different concepts that would certainly advance the process of costs evaluation and contribute to the increase of their visibility in the chain. ${ }^{13}$

In this sense, a new step in managing costs is the deepening of cooperation with suppliers, customers, and other organizations from the region, which as an integral part of the entire value chain involved in the creation and distribution of products to the final consumer. Today, the scientific literature prevalent opinion, a practice confirms that the competitive struggle going on between companies but between their value chains.

The companies which compete with costs on the market should focus their attention on the implementation of the integrated cost management program which will cover the entire life cycle of products along with a large number of links in the value chain. This means that efficient functioning of the entire value chain needs proper management and control of not only the internal value chain, but also the supply and distribution chains which are equally important for achieving the ultimate goal - satisfying consumer demands.

12 S. Malinic, M. Jankovic, 2011, Integrated Costs Management in Distribution Chain Strategic Approach and Managing -Accounting Information Support, Accounting 7-8, Association of Auditors and Accountants of Serbia, Belgrade, ps. 11-24

13 S. Malinic, D. Jovanovic, 2011, Implementation of Integrated Concepts of Costs Management in Distribution Chain - Strategic Approach TC and ABC, Accounting 11-12, Association of Auditors and Accountants of Serbia, Belgrade, ps. 29-44. 
However, without denying the importance of all the links of the entire value chain, in this paper we focus our attention on the company's internal value chain, and bearing in mind the mentioned characteristics of $\mathrm{ABC}, \mathrm{TC}$ and Kaizen Costing and the company's tendency to reduce costs, the process of integration of the three concepts follows. The tendency of the paper is to study the possibility of integrated application of modern cost accounting systems in the internal value chain in order to make a product that will give the entire value chain a foundation for creating a competitive product.

The price at which the final product is offered to the end consumer is not created solely within the company but it also depends on the efficiency of the distribution channels. In other words, the end users of a product on the market pay the total amount of costs and profit margins of all the participating organisations. ${ }^{14}$ Since it cannot influence the efficiency of the distribution channels, the company tends to, through an integrated application of cost accounting systems, to enable the final product to be cost competitive without compromising the desired characteristics and attributes.

We think that the visible results will be achieved in the domain of costs reduction in the production phase by integrated application of $\mathrm{ABC}, \mathrm{TC}$ and Kaizen concept that would provide synergy effect on the reduction of production costs. Such integration provides file management on ways of resource consumption through an internal chain. It requires cooperation between enterprises of all departments in terms of the exchange of financial information to integrated control costs give visible results.

TC, in the field of integration, should serve as a means of involving marketrelated information into the internal value chain. This primarily refers to the information on concrete products and their prices, suppliers, perception of consumers related to the product. TC, taking into account all the circumstances that prevail at the market, tries to find the optimal difference between the target selling price and target profit to define the target cost on the basis of which the product must be manufactured for the company to achieve the target profit.

The most effective application of TC is in the earliest stages of product development, when there is only the product design and its simultaneous development. At this stage, the cooperation and exchange of experience and knowledge among the design engineers involved in the product development create opportunities for the reduction of costs to the required level. This will enable the company to achieve a satisfactory level of profit and to keep the required characteristics of the product. The efficiency of TC application is higher if the methodology of $\mathrm{ABC}$ cost accounting system, a key tool in the field of production costs optimization, is built into the internal value chain.

14 Shank K. John., Govindarajan Vijay., (1992) „Strategic Cost Management: the Value Chain Perspectie“ Journal of Management Accounting Research, Fall, 180. 
The purpose of integrated application of $\mathrm{ABC}$ concept is to provide accurate information on individual costs based on the activities of consumers and suppliers so that the managers could eliminate the activities not creating value and redesign operational processes aimed at achieving or reducing total target costs. In the production process of the concrete product, application of $\mathrm{ABC}$ is also directed towards identification of the costs activities generated in the production process and costs drivers by which accurate allocation of costs to products is provided. It is also very important to make proper differentiation of the activities into the ones that add value and the ones that do not add value to the product so that the management can make proper assessment of the activities generating value in the internal value chain and the ones not generating value. ${ }^{15}$ Eliminating activities that do not contribute to creating value product can achieve significant savings in the consumption of limited resources, improving the quality of the internal value chain. In this way one gets insight into areas where it creates the greatest value for customers or field whose performance must improve. ${ }^{16}$

Unlike the traditional global costs allocation methods that proved as disadvantageous for financial result of the company, $\mathrm{ABC}$ system proved very efficient when allocating global costs, which is very significant from the point of view of cost management having in mind that under modern business conditions indirect costs participate in the product cost structure with over $60 \%$.

The significance of the integrated application of Kaizen costing in the internal value chain derives from the very essence of Kaizen concept. It is evident that Kaizen is directed towards the activities identified in the internal value chain. By application of Kaizen concept on such identified and differentiated activities by incremental changes, i.e. small savings in costs, in the long-term, significant effect in the cost reduction process ${ }^{17}$ would be provided.

Determining Kaizen costs per activity, particularly the activities not adding value and application of Kaizen concept per activity by applying techniques for continuous cost reduction, costs of internal value chain would gradually reduce which would enable achievement and reduction of the target costs. The technique that should be mentioned and, which is particularly significant for the internal value chain, is Quality Control, since, by application of this technique there are savings in costs occurring due to keeping in mind that deviation of quality and testing are minimized. Beside savings in costs this technique provides quality control of each activity performed in operations of the internal value chain.

15 More about add-value activiteise look Ljilja A. (2005) „Company Management Based on Activities”, XXXVI Symposium, Zlatibor, Zbornik radova, Association of Accountants and Auditors of Serbia, Belgrade, p.p.133-150.

16 Sekerez Vojislav (2011)

17 S. Malinic, M. Jankovic, 2011., Integrated Costs Management in Distribution Chain Strategic Approach and Management - Accounting Information Support, Accounting 7-8, Association of Auditors and Accountants of Serbia, Belgrade, ps. 11-24 
Application of this technique requires to create an environment in which both management and employees tend to perfection. This is achieved by introducing quality standards, adequate staff training and testing products to determine how much deviation from the adopted standards. Thus achieving significant savings of time and money invested in production.

Integrated application of $\mathrm{TC}, \mathrm{KC}$ and $\mathrm{ABC}$ provides the company management with information on possible sources of cost reduction. To get theses information one needs the analysis and evaluation of performances of each activity separately since only in this way one can achieve reduction and achievement of the desired costs.

This means that the initiating step of the integrated application of $\mathrm{ABC}$, $\mathrm{TC}$ and $\mathrm{KC}$, is defining the target selling price through information obtained by market research. The next step is defining the target cost which is, later on, decomposed to cost of material, components and business processes. It is followed by application of $\mathrm{ABC}$ method for costs calculation whereby the real costs of activities, material, components, functions and suppliers should be within previously defined target costs. Within this step, Kaizen concept is applied on the activities identified when applying $\mathrm{ABC}$ concept to observe the activities that spend too much resources and that represent potential field of cost reduction. If it is observed that there is a current cost gap the company management has to take steps to eliminate differences between current and target costs having in mind that if the company wants to keep to the idea of achieving profit the target costs must be achieved. Therefore, it is needed to do the analysis of all activities in the internal value chain, discover the causes of deviation and take the necessary steps for reducing costs to the desired level. The measures available to the company in this stage are the following: Value Engineering - VE, Business Process Reengineering - BRP, functional analysis, etc. In this way, one forms the model of feedback costs control in the closed loop form that enables better costs management along the entire value chain. ${ }^{18}$

The process of integrated application of $\mathrm{TC}, \mathrm{ABC}$ and $\mathrm{KC}$ in the internal value chain can be represented as in Figure 3.

18 MA Fei, YANG Hua, SUN Bao-feng 2008., WU Meng-na Remanufacturing System Cost Management Based on Integration of Target Costing and Activity-Based Costing, International Conference on Information Management, Innovation Management and Industrial Engineering, p.164. 
Figure 3: Integration of $\mathrm{TC}, \mathrm{ABC} i \mathrm{KC}^{19}$

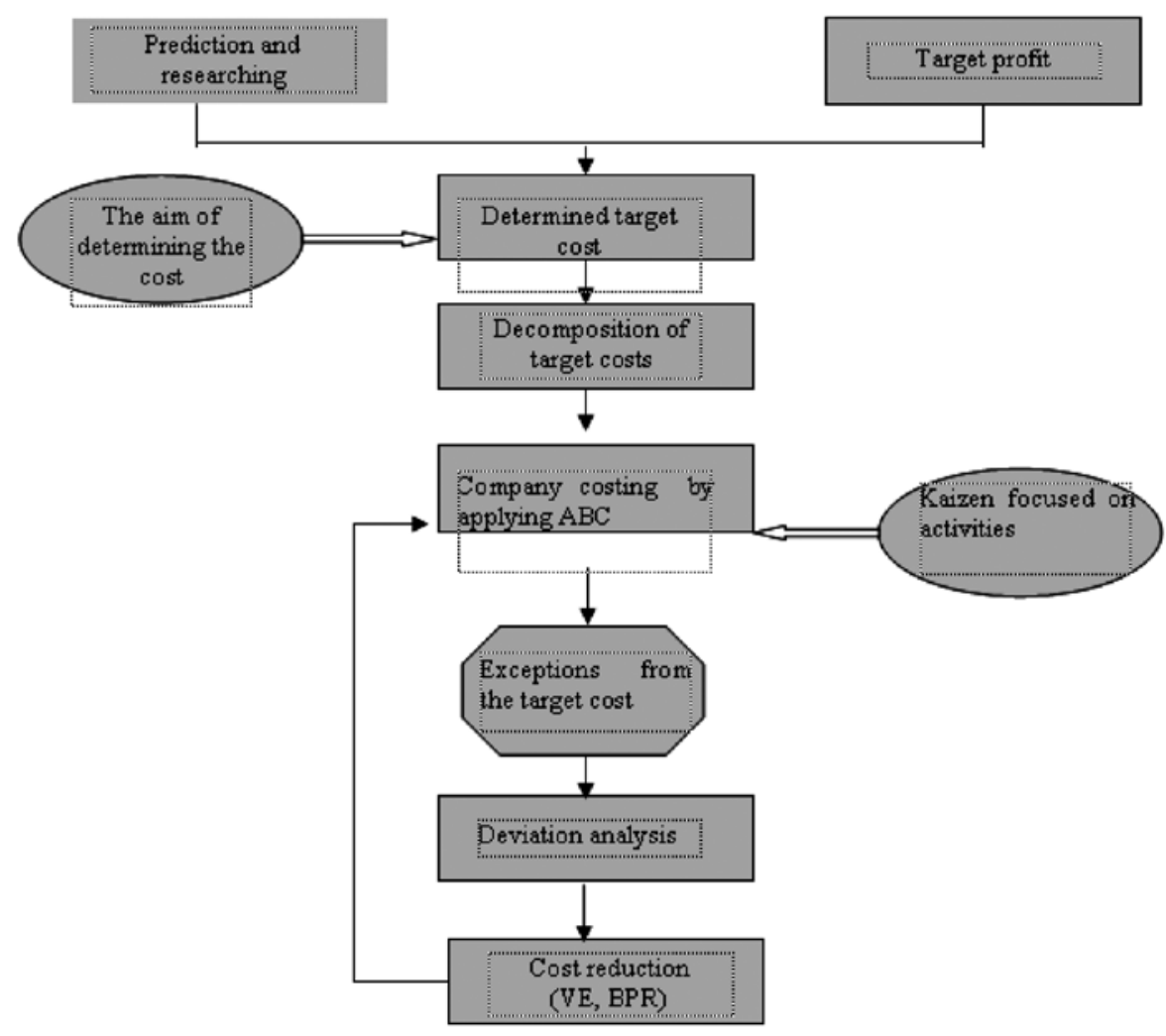

The objectives that a company wants to achieve with the integration of these three modern concepts of cost management are primarily:

- A more efficient use of the advantages that each system offers,

- A more efficient cost management since it provides greater cost savings,

- The creation of adequate accounting and information base which will help managers in their decision making.

Finally, we should say that despite great significance of integrated application of modern systems of costing in achieving of the synergy effect in the domain of reduction of operating costs, it is not "ideal" but, in terms of information it is better than individual application of some of the modern costing systems. These systems are not equally suitable for use in all companies and in all condit6ions. Therefore companies having the conditions and knowledge should use its advantages and also work on its further improvement and development and, at the same time, elimination of the observed deficiencies.

19 Adapted from Malinić Slobodan, Jovanović Dejan, (2011), 29-44. 


\section{Conclusion}

Key to integrated cost management is achievement of synergy effect, i.e. achievement of higher value than the value of simple sum of parts. To achieve competitive advantage generating value for the key stakeholders it is necessary to have cooperation between all links in the value chain since each link individually is very important for successful operation of the value chain. Therefore it is needed to have cooperation and exchange of information between all links in the value chain.

Without denying the value and importance of other links in the entire chain, internal value chain is yet the central link of the entire chain since, without it, it is not possible to create the product of the desired quality and functionality that will be competitive at the market. This means that the basic objective of the internal value chain is to find the optimal balance between costs and quality, i.e. to find the way to create superior value for consumer but with the lowest possible costs.

Application of TC, ABC and Kaizen concept, individually and particularly integrated can provide adequate results in achieving of more competitive internal chain which will create conditions for achievement of competitive advantage of the entire value chain and create value for all stakeholders. By integrated application of all three concepts cost management and more efficient control in the entire value chain are achieved. Detailed analysis of all costs of activities enables observing material, components and employees that are not efficient, i.e. it increases the transparency of costs so that the managers have clearer picture on what activities should be more efficiently managed and what activities should be eliminated with the purpose to achieve the target product costs. Application of Kaizen activities increases motivation of all participants in the internal value chain and their interactive cooperation which influences creation of creative ideas as the result of integration of different expertise. Application of Kaizen techniques for reduction of costs for each identified activity would provide savings in production costs without violation of the desired quality and functionality of the product and delays in the finalization of production.

Finally, a conclusion can be made that integrated application of TC, ABC and $\mathrm{KC}$ integrate strategic advantages of $\mathrm{TC}$ and operative advantages of $\mathrm{ABC}$ that, together with the techniques for the costs reduction and quality control create synergy effect in the area of cost management, and the managers are provided with the information basis for proper decision-making. 


\section{Literature}

- Antić Ljilja (2005) „Company Management Based on Activities”, XXXVI Symposium, Zlatibor, Zbornik radova, Association of Accountants and Auditors of Serbia, Belgrade, p.p.133-150.

- Cooper Robin , Caplan S. Robert., (1988), “How Cost Accounting Distors Products Cost", Management Accounting, April, ps. 20-27.

- Janjić Vesna (2011) „Implementation of Cost Leadership Strategy by Applying Kaizen Costing", Zbornik radova. 42 Symposium Accounting and Business Finance in Modern Business Conditions Quality of Financial Report - Challenges, Perspectives and Limitations, Association of Auditors and Accountants of Serbia, Zlatibor, $26^{\text {th }}-28^{\text {th }}$ May, ps. 359-377.

- Lalević-Filipović Ana, (2012), „The Possibility of Information Support of Target Costing by Generic Strategies of a Company, Accounting 1-2, Association of Accountants of Serbia, Belgrade, ps. 21-30

- MA Fei, YANG Hua, SUN Bao-feng (2008)., „WU Meng-na Remanufacturing System Cost Management Based on Integration of Target Costing and Activity-Based Costing", International Conference on Information Management, Innovation Management and Industrial Engineering, p. 164.

- Malinić Slobodan (2008), "Management Accounting", Faculty of Economics, Kragujevac, p. 239.

- Malinić Slobodan, Jovanović Dejan, (2011), „Implementation of Integrated Concepts of Costs Management in Distribution Chain - Strategic Approach TC and ABC", Accounting 11-12, Association of Auditors and Accountants of Serbia, Belgrade, ps. 29-44.

- Malinić Slobodan, Janković Marina, (2011), „Integrated Costs Management in Distribution Chain - Strategic Approach and Management Accounting Information Support", Accounting 7-8, Association of Auditors and Accountants of Serbia, Belgrade, ps. 11-24

- Milićević Vlade (2003), Strategic Management Accounting, Faculty of Economics, Belgrade, p. 130

- Milićević Vlade (2008) „Conventional management accounting - strategic issues", Economics of Enterprise, vol.56, br.3-4, Serbian Association of Economists,ps. 144-154.

- Milićević Vlade (2010), „A competitive cost management using value chain", Accounting 5-6, Association of Auditors and Accountants of Serbia, Belgrade, ps. 10-23

- Novićević Blagoje., Antić Ljilja., (2000), „New Concept of Costs Management - Calculation of Target Costing", Accounting 9, Association of Accountants of Serbia, Belgrade, ps. 13-20. 
- Porter Michael., (1996) „What is Strategy“, Harward Buisiness Review, novembar decembar, p.68.

- Sekerez Vojislav "Virtual Supply Chains as a Framework for Integrated Costs Management in Supply Chain"

- Sekerez Vojislav (2007) „The concept of cost management through the supply chain ", Proceedings of Symposium 38 Accounting and Business Finance in contemporary business conditions; Association of Auditors and Accountants of Serbia ps. 65-80.

- Sekerez Vojislav (2011) „Virtual supply chains as a framework for the integrated management of costs in the supply chain", naučni skup New methods of management and marketing in raising the competitiveness of the Serbian economy, Faculty of Economics Subotica. New methods of management and marketing in raising the competitiveness of the Serbian economy, Faculty of Economics Subotica..

- Shank K. John., Govindarajan Vijay, (1992) „Strategic Cost Management: the Value Chain Perspectie" Journal of Management Accounting Research, Fall, 180. 
Vesna Pašić Tomić, master

Fakultet za menadžment Zaječar,

Megatrend univerzitet, Beogarad

Doc. dr Maja Andrijašević,

Fakultet za menadžment Zaječar,

Megatrend univerzitet, Beogarad

\title{
UPRAVLJANJE TROŠKOVIMA U INTERNOM LANCU VREDNOSTI INTEGRISANOM PRIMENOM ABC, KAIZEN KONCEPTA I TARGET COSTINGA
}

\begin{abstract}
S a ž e $t$ a k
CIlj ovog rada jeste pokušaj da se sagledaju mogućnosti integrisane upotrebe Target Costing-a, Activity Based Costing-a i Kaizen koncepta u internom lancu vrednosti kao centralnoj karici ukupnog lanca. Ideja je podsticanje menadžmenta preduzeća na razmišljanje o troškovima, mestu koje zauzimaju u strukturi cene koštanja i njihovom uticaju na formiranje prodajne cene jer je veoma bitno proizvoditi pravi proizvod za kupca, željenog kvaliteta i funkcionalnosti ali uz što niže troškove proizvodnje. Zato je potrebno konstruisati pravi dizajn proizvoda i obezbediti da se proizvod proizvede u što kraćem roku i uz što niže troškove što će uticati na efikasnost ukupnog lanca vrednosti.
\end{abstract}

Ključne reči: integrisana primena, obračun troškova na bazi aktivnosti, kajzen obračun troškova, obračun ciljnog troška, interni lanac vrednosti 